\title{
A New Index for Identifying Technology Development in OECD Countries
}

\author{
Ben David Nissim, Garyn Tal Sharon \\ Department of Economics and Management, The Max Stern Yezreel Valley College, Jezreel Valley, Israel \\ Email: sharon.tal.garyn@gmail.com
}

How to cite this paper: Nissim, B.D. and Sharon, G.T. (2018) A New Index for Identifying Technology Development in OECD Countries. Modern Economy, 9, 443-448. https://doi.org/10.4236/me.2018.93029

Received: February 5, 2018

Accepted: March 18, 2018

Published: March 21, 2018

Copyright $\odot 2018$ by authors and Scientific Research Publishing Inc. This work is licensed under the Creative Commons Attribution International License (CC BY 4.0).

http://creativecommons.org/licenses/by/4.0/

\begin{abstract}
In this paper, we suggested a new technique for extracting a technology index time series and calculated the technology index for 26 OECD countries for the years 1990-2011. Assuming that production function is Cobb-Douglas and with constant return to scale and that the labor parameter is equal to the labor share out of the total production, we extracted the technology parameter for each year and for each country. According to our findings, the largest advance in technology occurred in Estonia, Slovenia, Poland, and Ireland while the smallest advance was in Italy, Portugal, Mexico and Japan. A possible explanation for these differences is foreign R\&D spillovers.
\end{abstract}

\section{Keywords}

Technology Index, OECD Countries

\section{Introduction}

In this paper, we calculated the technology index for 26 OECD countries for the years 1990-2011 using a new suggested index. Since many researchers had used the constant return to scale production function as representing the macro production process in developed economies [1] [2], we decided to rely on the same basis and assumed a Cobb-Douglas constant return to scale production function for each year in each OECD country. One of the major factors effecting productivity is technology, which we constructed and added into the production function. In the literature, we can find various techniques for calculating the technology factor as well as criticism regarding the use of a Solow residual [3] [4]. In this paper, we will present a simple technique of extracting a technology time series index for each country. 


\section{The Model}

\subsection{Production Function}

Let us assume that production function in period $\mathrm{t}$ is:

$$
F\left(K_{t}, L_{t}, T_{t}\right)=T_{t} K_{t}^{\alpha_{t}} L_{t}^{\beta_{t}}, \alpha_{t}+\beta_{t}=1
$$

$K_{t}$ is the amount of capital, $L_{t}$ is the number of workers, $T_{t}$ is technology level and $\alpha_{t}, \beta_{t}$ are parameters.

While in per-capita terms production per worker can be represented as ${ }^{1}$ :

$$
f\left(k_{t}, T_{t}\right)=T_{t} k_{t}^{\alpha_{t}}
$$

where $k_{t}$ is capital per capita in period $t$.

Given $N$ countries with different productivity of capital, the production function of each country $i$ is:

$$
f\left(k_{t}^{i}, T_{t}^{i}\right)=T_{t}^{i} k_{t}^{i \alpha_{t}^{i}}, i=1,2, \cdots, N
$$

Assuming that each country has a Cobb-Douglas constant return to scale production function, as presented in Equation (1), we first had to estimate the share of labor out of national income (the parameter $\alpha_{t}^{i}$ ) for each country $i$ and time $t$.

\subsection{Share of Labor out of GDP}

In order to estimate $\alpha_{t}^{i}$ we used the fact that labor income share out of total productivity in country $i$ at time $\mathrm{t}$ is equal to $\alpha_{t}^{i}$. Collecting data for the number of employees ${ }^{2}$ and the average annual wage ${ }^{3}$ for the years 1990-2011, we calculated the total wage payments in each economy. Dividing it by $\mathrm{GDP}^{4}$ we get $\alpha_{t}^{i}$.

Our results show that Czech Republic, Greece, France, Italy, Portugal and Spain are the countries with the highest share of labor income out of GDP while Switzerland, United Kingdom, Netherland, Denmark and Australia are the countries with the lowest share of labor.

Given $\alpha_{t}^{i}$ we get that the share of capital is $\beta_{t}^{i}=1-\alpha_{t}^{i}$.

\subsection{Technology Index}

Recall that the production function of each country $i$ is

$$
f\left(k_{t}^{i}, T_{t}^{i}\right)=T_{t}^{i} k_{t}^{i \alpha_{t}^{i}}, t=1,2, \cdots, T ; i=1,2, \cdots, N
$$

Rearranging (3) we get:

$$
T_{t}^{i}=\frac{f\left(k_{t}^{i}, T_{t}^{i}\right)}{k_{t}^{i \alpha_{t}^{i}}}, t=1,2, \cdots, T ; i=1,2, \cdots, N
$$

\footnotetext{
${ }^{1}$ We divided the two sides of equation (1) by L-the number of workers in the economy.

${ }^{2}$ Calculated as product of 2 series: "Population, total" and "Employment to population ratio, 15+, total (\%) (national estimate)", both extracted from the world bank data.

${ }^{3}$ Extracted from OECD-I library.org.

4"GDP at market prices" extracted from the world bank data.
} 
Thus, according to (4), we calculated the technology parameter for each country $i$ at time $t$ by dividing GDP per capita at time $t$ by the factor $k_{t}^{i \alpha_{t}^{i}}$ i.e. by capital per capita at time $t$ raised by the share of labor out of GDP for country $i$ at time $t$.

We normalized the capital stock, number of employees, and technology to equal 1 in $1996^{5}$.

Figure 1 presents the technology index in 2011, as was extracted by us for all countries (relative to a benchmark index equals 1 in 1996).

We find that the greatest advance in technology from 1996 to 2011 is in Estonia, Poland, Czech Republic, Slovenia and Ireland, while the smallest advance in technology is in Spain, Italy, Portugal, Mexico and Japan.

\section{Discussion}

The economic literature discusses the idea that growth in conventional inputs explains only part of the observed growth in output. The major source of productivity growth was seen as coming from an improvement in the quality of labor and capital as well as from technological changes which are a product of R\&D investment and R\&D spillover. The pioneers of this subject were Fabricant [5], Abramovitz [6], Kendric [7] and Solow [8] and more lately Wolfgang [9] and Spulber [10], among many others.

In this paper, we wish to suggest a simple technique for empirically identifying the level of improvement in technology along a time path in various OECD countries.

Assuming that production function is Cobb-Douglas and has a constant return to scale and that the labor parameter is equal to the labor share out of the total production, we can extract the technology parameter for each year and for each country.

We find that there exists a large difference in technological progress among the OECD countries, with the highest progress in Estonia, Slovenia, Poland and

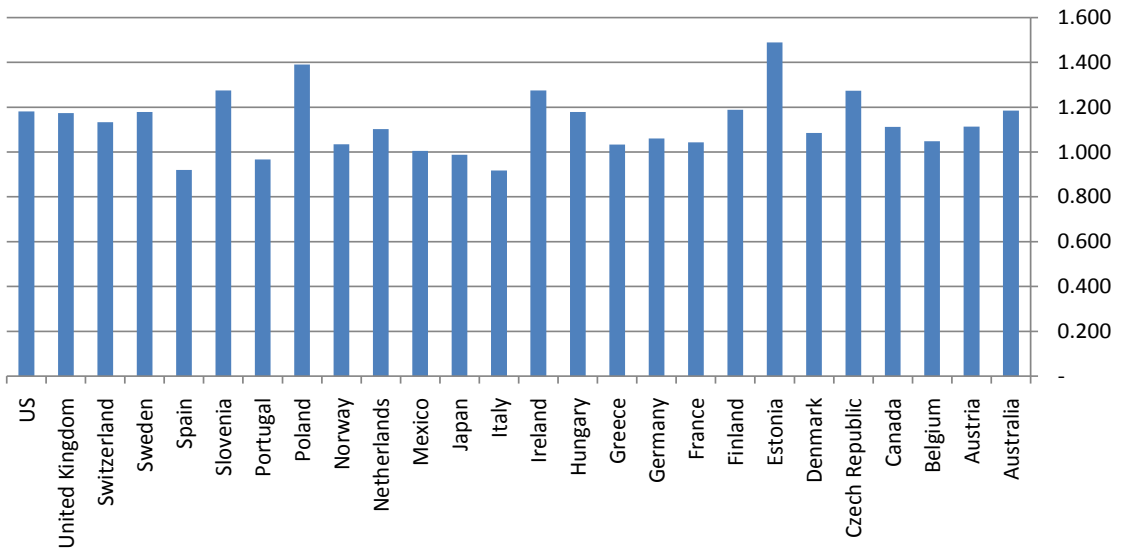

Figure 1. Technology index in 2011 (set to 1 in 1996).

${ }^{5}$ For eastern European countries, we could only find data for the period starting in 1996, while for other OECD countries data starts in 1990. 
Ireland while the smallest is in Italy, Portugal, Spain and Japan. One question we need to ask is why there is such a large difference in technological progress among the OECD countries and more specifically why the highest progress is in the former while the smallest is in the latter.

It should be noted that Estonia, Slovenia, and Poland are developing countries which were former parts of the Soviet Union and were exposed to greatly increased international trade after the collapse of the Soviet Union, while Ireland greatly increased its volume of international trade and foreign direct investment in the last two decades. The literature suggests that a country can improve its Total Factor Production by profiting from the foreign R\&D spillovers through international trade or the import of investment and capital goods coming from developed countries and communication links. In addition to opening itself to the outside, a country must be geographically close to a possible source of foreign technology, thus accounting for the geographical localization of international technology diffusion. The improvement of the absorptive capacity of the developing country can increase when it invests more in $R \& D$, when it has a good education system, and when it has large Foreign Direct Investment (FDI) through acquisitions by foreign multinational firms. The idea of technology transmission through international trade (i.e. imports) has been supported by many researchers and in particular by Sjöholm [11], Coe, Helpman and Hoffmaister [12], Keller [13], and Mayer [14]. Two papers of Eaton and Kortum [15], [16] also focused on the importance of trade for international technology diffusion. Therefore, as the size of the R\&D spillovers between the industrialized countries depends mainly on the amplitude of the trade relations between these countries, they tend to be particularly large between the European countries on the one hand and the United States and Canada on the other hand, which maintains strong trade relations. Helpman [17] tried to evaluate the extent of international R\&D spillovers by suggesting that it needs to identify a variable which correctly reflects their influence: the Total Factor Production (TFP). In other words, the author examined how the R\&D investment in one country affects the TFP of other economies. Coe and Helpman [18] found great effects of domestic and foreign R\&D capital stocks on the TFP. Within this framework, the TFP of a developed country depends not only on its own R\&D capital stock, but also on R\&D capital stocks of its trade partners. Moreover, the empirical results of Lichtenberg and Van Pottelsberghe de la Potterie [19] confirmed that the more a country is opened to foreign trade, the more it is probable to profit from foreign R\&D.

Aside from this, Keller [13] tried to quantify the importance of trade in the determination of technology flows which affect productivity by using data at the level of industry for the imports of goods and productivity in 8 countries of the OECD (i.e. G7 + Sweden) during the period 1970-1991. The author concluded that the marginal effect of bilateral trade contributes to nearly $20 \%$ of its capacity to account for the effects in terms of productivity growth of international $R \& D$ spillovers or of foreign R\&D. 
Eaton and Kortum [15] [16] combined the structure of technology diffusion and growth in Eaton and Kortum [20] with that of the Ricardian model elaborated by Dornbusch, Fisher and Samuelson [21]. The two authors found that the productivity level of a country is connected to its implicit access to foreign technology through the imports of goods. Keller [22] [23] [24] used the bilateral language knowledge to examine the importance of communication for international technology diffusion among the G7 countries as well as among the OECD countries. For example, in the first case, language knowledge has the highest contribution to technology diffusion in the United Kingdom and the weakest one in Japan.

What could be the explanation for the smallest advance in technology which Italy, Portugal, Mexico and Japan experienced?

Coe and Helpman [18] analyzed the extent to which technological activities are diffused between the industrialized countries through a particular channel of trade flows. They showed that these countries enjoy a substantial benefit from the R\&D made by their trade partners. Therefore, although the domestic R\&D capital stock has an effect on the TFP in the large developed countries compared with the smaller developed countries, the latter are opened and consequently profit from the foreign R\&D more than bigger countries. This explanation may apply to Italy and Japan, relatively large developed economies with smaller technological diffusion from other countries, a result that is consistent with Okubo [25]. Okubo found that the larger the difference in GDP and factor endowments is, as is the case in North-South countries, the more it is probable that the technology transfer takes place. On the other hand, the smaller the difference in GDP and factor endowments, the less probable it is that technology transfer takes place. A deeper analysis should be done in future research in order to explain our results of a small advance in technology that occurred in Portugal and Mexico.

\section{References}

[1] Masanjala, W.H. and Papageorgiou, C. (2004) The Solow Model with CES Technology: Nonlinearities and Parameter Heterogeneity. Journal of Applied Econometrics, 19, 171-201. https://doi.org/10.1002/jae.722

[2] Papageorgiou, C. and Saam, M. (2008) Two Level CES Production Technology in the Solow and Diamond Growth Models. The Scandinavian Journal of Economics, 110, 119-143. https://doi.org/10.1111/j.1467-9442.2008.00529.x

[3] Hartley, J.E. (2000) Does the Solow Residual Actually Measure Changes in Technology? Review of Political Economy, 12, 27-44. https://doi.org/10.1080/095382500106803

[4] Otto, G. (1999) The Solow Residual for Australia: Technology Shocks or Factor Utilization? Economic Inquiry, 37, 136-153. https://doi.org/10.1111/j.1465-7295.1999.tb01421.x

[5] Fabricant, S. (1954) Economic Progress and Economic Change. NBER.

[6] Abramovitz, M. (1956) Resource and Output Trends in the United States since 1870. NBER, 1-23. 
[7] Kendrick, J. (1956) Productivity Trends: Capital and Labor. The Review of Economics and Statistics, 38, 248-257. https://doi.org/10.2307/1925777

[8] Solow, R.M. (1956) A Contribution to the Theory of Economic Growth. Quarterly Journal of Economics, 70, 65-94. https://doi.org/10.2307/1884513

[9] Wolfgang, K. (2004) International Technology Diffusion. Journal of Economic Literature, 42, 752-782. https://doi.org/10.1257/0022051042177685

[10] Spulber, D. (2008) Innovation and International Trade in Technology. Journal of Economic Theory, 138, 1-20. https://doi.org/10.1016/j.jet.2007.06.002

[11] Sjöholm, F. (1996) International Transfer of Knowledge: The Role of International Trade and Geographic Proximity. Weltwirtschaftliches Archiv, 132, 97-115. https://doi.org/10.1007/BF02707904

[12] Coe, D.T., Helpman, E. and Hoffmaister, A. (1995) North-South R\&D Spillovers. NBER, No. w5048.

[13] Keller, W. (1998) Are International R\&D Spillovers Trade-Related? Analyzing Spillovers among Randomly Matched Trade Partners. European Economic Review, 42, 1469-1481. https://doi.org/10.1016/S0014-2921(97)00092-5

[14] Mayer, J. (2001) Technology Diffusion, Human Capital and Economic Growth in Developing Countries. United Nations Conference on Trade and Development.

[15] Eaton, J. and Kortum, S. (2001) Trade in Capital Goods. European Economic Review, 45, 1195-1235. https://doi.org/10.1016/S0014-2921(00)00103-3

[16] Eaton, J. and Kortum, S. (2002) Technology, Geography, and Trade. Econometrica, 70, 1741-1779. https://doi.org/10.1111/1468-0262.00352

[17] Helpman, E. (1988) Growth, Technological Progress, and Trade. NBER. https://doi.org/10.3386/w2592

[18] Coe, D.T. and Helpman, E. (1995) International R \& D Spillovers. European Economic Review, 39, 859-887. https://doi.org/10.1016/0014-2921(94)00100-E

[19] Lichtenberg, F.R. and De La Potterie, B.V.P. (1998) International R \& D Spillovers: A Comment. European Economic Review, 42, 1483-1491. https://doi.org/10.1016/S0014-2921(97)00089-5

[20] Eaton, J. and Kortum, S. (1999) International Technology Diffusion: Theory and Measurement. International Economic Review, 40, 537-570. https://doi.org/10.1111/1468-2354.00028

[21] Dornbusch, R., Fischer, S. and Samuelson, P.A. (1977) Comparative Advantage, Trade, and Payments in a Ricardian Model with a Continuum of Goods. The American Economic Review, 67, 823-839.

[22] Keller, W. (2001) Knowledge Spillovers at the World's Technology Frontier. CEPR Working Paper, 2815.

[23] Keller, W. (2001) The Geography and Channels of Diffusion at the World's Technology Frontier. NBER, w8150.

[24] Keller, W. (2004) International Technology Diffusion. Journal of Economic Literature, 42, 752-782. https://doi.org/10.1257/0022051042177685

[25] Okubo, T. (2007) Intra-Industry Trade, Reconsidered: The Role of Technology Transfer and Foreign Direct Investment. The World Economy, 30, 1855-1876. https://doi.org/10.1111/j.1467-9701.2007.01073.x 